\title{
UM ESBARRO TITUBEADO NO NARRADOR EVANESCENTE
} A HALTING STUMBLE IN THE EVANESCENT NARRATOR

\author{
Daniel Augusto do Nascimento Batista ${ }^{1}$
}

Recebido em: 11 set. 2018

Aceito em: 17 dez. 2018

DOI 10.26512/aguaviva.v4i2.23840

RESUMO: Este artigo analisa o conto $O$ Espelho, de Guimarães Rosa, e identifica um tipo peculiar de narrador caracterizado pela evanescência - isto é, incapaz de se enxergar no próprio discurso -, que, por analogia, também se faz presente no quadro Las Meninas, de Diego Velázquez, como se mostra em cotejamento complementar.

Palavras-chave: Guimarães Rosa; $O$ Espelho; Las Meninas; Diego Velázquez; Narrador evanescente.

ABSTRACT: This article analyzes the short story $O$ Espelho, by Guimarães Rosa, and identifies a peculiar type of narrator characterized by evanescence - that is, unable to see himself in his own discourse -, which, analogously, is also present in the painting Las Meninas, by Diego Velázquez, as shown in a complementary comparison.

Keywords: Guimarães Rosa; O Espelho; Las Meninas; Diego Velázquez; Evanescent narrator.

Já em sua maturidade literária, em 1962, poucos anos antes de morrer, João Guimarães Rosa publicou Primeiras Estórias, volume de contos que contém alguns textos que se tornariam célebres e centrais em sua obra, como A Terceira Margem do Rio e O Espelho, que aqui será brevemente analisado.

\footnotetext{
${ }^{1}$ Mestre em Meios e Processos Audiovisuais pela Escola de Comunicações e Artes da Universidade de São Paulo (ECA-USP), financiado pela FAPESP. Graduado em Imagem e Som pela Universidade Federal de São Carlos (UFSCar), com Iniciação Científica também financiada pela FAPESP. Graduando em Direito pela Faculdade de Direito da Universidade de São Paulo (FD-USP) e pela Université Lumière Lyon 2 em convênio de dupla titulação (PITES - Partenariat International Triangulaire d'Enseignement Supérieur). Membro do NUDRAMA (Grupo de Estudos de Dramaturgia Audiovisual) e do GEDD (Grupo de Estudos de Direito Desportivo) da tragicomédia no Século de Ouro Espanhol" com bolsa FAPESP. E-mail: dnaugusto@gmail.com
} 
Ao contrário do tom eminentemente regionalista e linguisticamente experimental das obras que consagraram o escritor (Sagarana, de 1946, e Grande Sertão: Veredas, de 1956), O Espelho não faz quase nenhuma referência direta ao recorrente ambiente rural de seu autor e é composto por uma linguagem acurada, correta e com certo viés ensaístico, embora não sem algumas palavras características do léxico rosiano.

Narrado em forma de uma extensa fala de um personagem cujo nome não se conhece direcionada a um interlocutor do qual pouco se pode saber, o conto consiste não numa aventura, mas numa experiência interior, como já avisa o narrador. Este, ao longo de seguidas lucubrações acerca da natureza dos espelhos e daqueles que neles se refletem, apresenta crenças permeadas pelo medo em relação à misteriosa superfície reflexiva ("na nossa terra, diz-se que nunca se deve olhar em espelho às horas mortas da noite, estando-se sozinho"), mas se põe como homem orientado pela racionalidade e afeito a investigações (“Sou, porém, positivo, um racional, piso o chão a pés e patas. Satisfazer-me com fantásticas não-explicações? - jamais”)

Adiante, ele fala sobre o ponto de partida de sua experiência: um dia, quando ainda moço, num lavatório público, viu atrás de si um sujeito abjeto que lhe causou repulsa. Mas logo se surpreendeu ao notar que aquela imagem era seu reflexo e que não o havia percebido antes porque não atentara ao fato de haver dois espelhos - que faziam jogo - no local.

A partir daí o narrador inicia incessante busca por sua verdadeira forma. Encara o espelho de diversos modos, em diversas circunstâncias. Justifica-se: "Sendo assim, necessitava eu de transverberar o embuço, a travisagem daquela máscara, a fito de devassar o núcleo dessa nebulosa - a minha vera forma”. Logo nota que, para alcançar uma imagem que seja só sua, deve subtrair tudo aquilo identificadamente externo, alheio a seu ser, da aparência que vê refletida.

Começa por identificar sua semelhança com um animal - elege a onça. Então se disciplina para ignorar os traços que recordam o felino em sua imagem. As lacunas que brotam em seu reflexo explicitam os progressos do método. Mas ainda há o que se subtrair para alcançar a verdadeira forma: a seguir, o narrador passa a ignorar seus traços hereditários - "parecenças com pais e avós" - e as expressões momentâneas, motivadas por estados emocionais.

Neste itinerário, ainda que se aproxime de seu objetivo, tem um acesso de fraqueza, isto é, decide parar a peculiar busca, o que, a propósito, não significa que nunca mais torna a se por defronte de um espelho. Alguns anos depois, topa acidentalmente com um, mas, para sua absoluta estranheza, não enxerga nada como reflexo. Ironicamente, numa circunstância na qual gostaria de se encarar, não vê nada, apesar do esforço. Suas palavras mostram a melancolia daí 
advinda: "E a terrível conclusão: não haveria em mim uma existência central, pessoal, autônoma? Seria eu um... des-almado? Então, o que se me fingia de um suposto eu, não era mais que, sobre a persistência do animal, um pouco de herança, de soltos instintos, energia passional estranha, um entrecruzar-se de influências, e tudo o mais que na impermanência se define?"

Resignado, o narrador não tenta mais se ver refletido. Entretanto, mais uma vez, após alguns anos, topa com um espelho e se surpreende: vê surgir uma pequena luz, "o tênue começo de um quanto como uma luz, que se nublava, aos poucos tentando-se em débil cintilação, radiância. " E então, muito mais tarde, numa altura em que já amava ("Por aí, perdoe-me o detalhe, eu já amava”) finalmente vê outra imagem - "o ainda-nem-rosto [...] E não era mais que: rostinho de menino, de menos-que-menino, só. "Neste ponto, termina a história que o narrador conta para seu interlocutor, ao qual se associa como servo ("Solicito os reparos que se digne dar-me, a mim, servo do senhor [...]")

À maneira de um mapa-múndi, aí estão os contornos do enredo apresentado no conto. É possível ver toda sua superfície, seus oceanos de águas estáticas. Poder-se-ia fixá-lo na parede e admirar a beleza do que salta à vista. Mas, procedendo-se simplesmente assim, perde-se o brilho de duas dimensões que aqui serão exploradas: uma cravada nas fossas abissais do mundo em questão, a partir da qual se perceberá que suas águas não são nada estáticas, e outra, mais universal, calcada num astro que o circunda e influencia suas marés.

Assim, passa-se à primeira dimensão, adentra-se nas profundas águas do conto. Nesta altura, é preciso ter em conta os elementos que dão aspecto às imagens que o narrador vê refletidas no espelho. Facilmente, identificam-se três: um animal (a onça), os ascendentes (pais e avós) e o amor. Note-se que ambos os elementos citados têm um caráter que se pode chamar de social, já que estão baseados em relações entre diferentes sujeitos ou em sistemas socialmente definidos.

A ver, isoladamente: a referência à associação de um animal a um sujeito - no caso, o narrador - remete ao totemismo, credo religioso característico de muitos povos primitivos em que os sujeitos se filiavam a um totem, amiúde um animal ${ }^{2}$; a presença das figuras dos ascendentes fala não só de simples herança genética, mas de uma autoridade a que o narrador já foi submetido e de que tenta se livrar ao se olhar no espelho; e o amor se trata da relação com

\footnotetext{
${ }^{2}$ É, no mínimo, interessante notar as concomitantes associações do narrador ao totemismo e à tradição científica. Paradoxalmente, pinta-o como primitivo e racional. Sem dúvida, um artifício do autor para manifestar uma vez mais a dualidade pela qual se celebrizou em Grande Sertão:Veredas.
} 
um personagem que, embora desconhecido, tem tamanha força que transcende as barreiras do meramente social para mudar a maneira como o narrador vê a si mesmo.

Torna-se claro que, mesmo que se centre na situação de um homem em conflito com sua essência, o conto está permeado de caracteres sociais que influem de modo muito ativo e até misterioso em algo tão individual como um pensamento ao se dar uma olhadela no espelho. Sendo assim, é oportuno trazer à baila um comentário de Theodor Adorno:

O impulso característico do romance, a tentativa de decifrar o enigma da vida exterior, converte-se no esforço de captar a essência, que por sua vez aparece como algo assustador e duplamente estranho no contexto do estranhamento cotidiano imposto pelas convenções sociais (ADORNO, 2003, p. 58).

Ainda que trate do romance, o comentário tem grande relevância para esta análise, uma vez que esclarece a natureza das imagens vistas pelo narrador no espelho. Ele, em busca de sua essência, tenta prescindir das convenções sociais que o tocam, mas só encontra estranheza nas imagens. Não pode, enfim, definir a si mesmo sem se voltar a algo exterior. E é especialmente irônico o modo como essa exterioridade - em grande parte social, como já se disse - se manifesta em todo o conto, inclusive na própria narração, que, como é revelado ao final, não passa de um fragmento de uma conversa entre um patrão e um servo.

À luz do que se revelou nas profundezas do texto, já é possível tomar fôlego para partir para o astro que gravita em torno dele. Porém, antes de percorrer o caminho que leva até lá, fazse necessário estabelecer uma ponte que leve direto ao ponto desejado - e aqui se estabelece uma chamada Julio Cortázar. No ensaio, Alguns aspectos do conto ${ }^{3}$, ele diz que o cinema está para o romance assim como a fotografia está para o conto. Ora, se uma fotografia é uma imagem estática que não tem a capacidade narrativa nem a extensão cinematográficas, infere-se que não há diferença em substituí-la pela pintura, sua irmã mais velha.

Destarte, já se definiu que a forma conto se associa à pintura, mas ainda resta esclarecer: especificamente a qual quadro se associa o conto aqui analisado? Para obter a resposta, é preciso transcender os limites de $O$ Espelho e ir até o século XVII, a uma de suas mais conhecidas e estudadas obras: Las Meninas, de Diego Velázquez. No entanto, antes de se poder estabelecer o que há de universal que a liga à obra rosiana, deve-se atentar brevemente aos finos traços do pintor.

\footnotetext{
${ }^{3}$ In: Valise de Cronópio, São Paulo: Perspectiva, 1993.
} 
Num primeiro exame, o que se vê é um monte de gente e um cão num pequeno cômodo e um homem ao fundo, não se sabe se chegando ou indo embora, mas, por sua posição, nota-se que está em movimento. Este, aliás, é o menos visível, de modo que o ambiente e os outros presentes constituem objetos de análise mais auspiciosos. A seguir, num exame posterior, identifica-se um pintor à direita - devido ao pincel e à palheta que tem em mãos -, quatro figuras de caráter pouco destacado à esquerda (uma anã, uma criança que põe o pé sobre o cão, uma freira e uma pessoa pouco identificável) e, ao centro, uma criança que se destaca por sua pompa e atrai a atenção absoluta de duas garotas também pomposas, mas num grau menor, menos conspícuo. Quanto ao ambiente, vê-se que se trata de um ateliê, a partir das presenças de uma grande tela à frente do pintor e de vários quadros, ainda que obscuros, nas paredes. Ao lado do homem ao fundo, no entanto, um quadro chama a atenção por estar fortemente iluminado. Nele, distinguem-se, nebulosas, duas formas humanas, uma mulher e um homem. O observador deve se perguntar: mas por que há um quadro distintamente iluminado?

Todavia, logo se nota que a questão não tem validade. Algumas das pessoas identificadas há pouco olham para frente, para um mesmo ponto. A criança pomposa, o pintor, a anã e até mesmo o homem ao fundo. Deste modo, tudo leva a crer que o quadro é, na verdade, um espelho que reflete o centro da atenção da situação, ou seja, os modelos que são pintados pelo pintor. A configuração daí advinda e algum conhecimento histórico possibilitam a identificação das pessoas: o pintor é o próprio Velázquéz, a criança pomposa é a infanta Margarita, as garotas que a acompanham são suas aias, os outros visíveis na tela são cortesãos e, por fim, o casal refletido é formado pelo rei Filipe IV e sua esposa Mariana.

Mas a identificação das figuras históricas tem pouca relevância. Aqui o interesse é analisar as relações narrativas que o quadro estabelece. Partindo para essa vereda, é impossível fugir da questão: quem é o narrador? Isto é, sob qual ponto de vista se vê o quadro? Em geral, a resposta é muito simples - o pintor. Mas, no caso que nos interessa, o pintor se eximiu de narrar o que se vê; ele, ao contrário, faz parte do todo visto. Então, decorre que o narrador é alguém que está fora do quadro, alguém que empresta os olhos ao espectador, mas que não é o pintor. Neste caso, o espelho serve de evidência: o narrador faz parte do casal real. Afinal, o ponto de vista do espectador coincide absolutamente com o dos modelos.

Já com o narrador identificado em conta, parte-se para a imagem. Como já se pode notar, o que é apresentado é um complexo e verossímil retrato que contém vários indicativos de relações sociais estabelecidas entre o narrador e as pessoas que se vê. O homem ao fundo parece um subalterno que vem dar algum aviso, os cortesãos assistem o casal, o pintor realiza um 
trabalho pelo qual foi ou será pago, a infanta Margarita tem seu momento de entretenimento ao conhecer o ateliê do contratado de seus pais e suas aias não deixam de cortejá-la. A partir do indicado, fica fácil notar que o narrador, seja Filipe IV ou Mariana, se define muito bem em relação aos que o circundam. Mas a questão que aqui interessa é: como o narrador vê a si mesmo?

Por fim, chega-se ao espelho da obra. A parte mais enigmática. Com o auxílio da argúcia de Michel Foucault ${ }^{4}$, pode-se ampliar o enigma do espelho sem ainda entrar na questão da essência que se vê. Duas incongruências: a luz do espelho é muito brilhante, diferente daquela que entra pela direita do quadro e que parece ser a natural; e o reflexo que se vê poderia ser o duplo perfeito, ou seja, poderia refletir as costas do pintor e da infanta, o quadro e só depois as formas do casal real. Nota-se, então, que o perímetro do espelho escapa à verossimilhança que permeia todo o restante da visão. E por quê? Por que o reflexo do espelho tem justamente o rosto do casal como centro? Por que o espelho brilha, se destacando de todo o resto? A explicação que logo surge é um narcisismo egocêntrico, o mesmo que faz com que o narrador ponha tudo e todos à sua volta. Porém, a despeito de sua vaidade, ele não se vê claramente no espelho. Ainda que se possa ver um casal pintado com roupas reais, uma nebulosidade paira sobre a essência projetada. Não se vê muito mais do que isso.

Assim como o narrador de $O$ Espelho, o de Las Meninas só consegue se definir naquilo que diz respeito à exterioridade. Trocando em miúdos, ambos não logram se definir senão em relação àquilo que não são. Afora isso, o que lhes sobra nada mais é do que a estranheza de uma imagem nebulosa de si mesmos. Deste modo, nas duas obras, encontra-se um tipo de narrador que tenta buscar sua essência, mas só encontra uma eterna imagem evanescente.

Embora não com o devido cuidado analítico, talvez aqui se tenha chegado ao que se buscou de universal. Afinal, parece cabível definir assim algo que é válido tanto no século XVII quanto no XX. E, indo mais fundo, será exagero dizer que as pessoas - sobretudo hoje, no mundo dos currículos, cheios de autorreferências - não sabem se definir, num discurso ou numa imagem, senão em relação àquilo que não são?

\section{REFERÊNCIAS}

ADORNO, Theodor. Posição do narrador no romance contemporâneo. In: Notas de Literatura I, São Paulo: Editora 34, 2003.

\footnotetext{
${ }^{4}$ O primeiro capítulo de seu livro Le mots et les choses (1966) é um ensaio integralmente dedicado ao Las Meninas.
} 
Revista Água Viva

CORTAZAR, Julio. Alguns aspectos do conto. In: Valise de cronópio, São Paulo: Perpectiva, 1993.

FOUCAULT, Michel. Les suivantes. In: Les mots et les choses, Paris: Gallimard, 1966.

ROSA, Guimarães. Grande Sertão: Veredas, Rio de Janeiro: Nova Fronteira, 2001.

ROSA, Guimarães. O Espelho. In: Primeiras Estórias, Rio de Janeiro: José Olympio, 1974. 